\title{
Thyrotropin Secreting Pituitary Adenoma Accompanying a Silent Somatotropinoma
}

\author{
Tirotropin Sekrete Eden Pituiter Adenoma Eşlik Eden Sessiz \\ Somatotropinoma
}

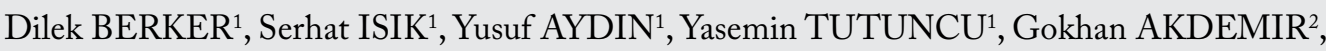 \\ Hatice NURSUN OZCAN ${ }^{3}$, Serdar GULER ${ }^{1}$ \\ ${ }_{1}^{1}$ Ministry of Health, Ankara Numune Research and Training Hospital, Department of Endocrinology and Metabolism, Ankara, Turkey \\ ${ }^{2}$ Ministry of Health, Ankara Numune Research and Training Hospital, Department of Neurosurgery, Ankara, Turkey \\ ${ }^{3}$ Ministry of Health, Ankara Numune Research and Training Hospital, Department of Radiology, Ankara, Turkey
}

Correspondence address: Dilek BERKER / E-mail: dberker6@yahoo.com

\begin{abstract}
Thyroid stimulating hormone (TSH) secreting pituitary adenomas are rare tumors manifested as hyperthyroidism with goiter in the presence of elevated TSH. We present a case with pituitary adenoma secreting both TSH and growth hormone (GH) with the prominent clinical findings of hyperthyroidism but without clinical findings of acromegaly. Pituitary magnetic resonance imaging revealed a macroadenoma. Transsphenoidal surgery was performed twice. The immunohistochemical staining showed that tumor cells were strongly reactive to $\mathrm{GH}$ and relatively mildly reactive to TSH. Control pituitary imaging revealed a residual macroadenoma, and long acting octreotide treatment was administered. After two years of the treatment, tumor size remained the same while thyroid function tests and insulin-like growth factor 1 (IGF-I) values returned to normal ranges. In conclusion, we always recommend hormonal examinations for all patients who have pituitary adenoma without signs and symptoms of acromegaly.
\end{abstract}

KEYWORDS: Thyrotropin, Pituitary adenoma, Growth hormone, Acromegaly

öz

Tiroid stimule edici hormon (TSH) salgılayan pituiter adenomlar yüksek TSH seviyeleri ile birlikte hipertiroidi ve guatrın görüldüğü nadir tümörlerdir. Akromegali klinik bulgularının görülmediği, ön planda hipertiroidi kliniğinin yer aldığı TSH ve büyüme hormonu (GH) salgılayan piuiter adenomlu bir vakayı sunuyoruz. Pituiter manyetik rezonans görüntülemede makroadenom tespit edilerek iki defa transsfenoidal cerrahi uygulandı. İmmünhistokimyasal incelemede güçlü bir şekilde GH ve daha az oranda TSH ile boyanma izlendi. Kontrol pituiter görüntülemesinde rezidü makroadenom görülmesi nedeniyle uzun etkili oktreotid başlandı. İki yıllık tedavi sonrasında tümor boyutu sabit kalırken tiroid fonksiyon testleri ve insulin benzeri büyüme faktörü 1 (IGF-I) düzeyleri normale döndü. Sonuç olarak akromegali klinik bulguları olmasa dahi her zaman pitüiter adenomu olan hastaların değerlendirilmesinde hormonal incelemelerin yapılmasını öneriyoruz.

ANAHTAR SÖZCÜKLER: Tirotropin, Pituiter adenom, Büyüme hormonu, Akromegali

\section{INTRODUCTION}

Thyrotropin (thyroid stimulating hormone, TSH) -secreting adenomas (TSH-oma) are the least common type of tumors representing less than $1 \%$ of the total pituitary adenomas (3). Several untreated patients with TSH-oma were described as clinically euthyroid (2). Moreover, hyperthyroid features can be overshadowed by those of acromegaly in patients with mixed TSH/ growth hormone (GH) adenomas (4). We present an unusual case with pituitary adenoma co-secreting TSH and $\mathrm{GH}$ with signs of hyperthyroidism but without signs of acromegaly. 
tags. Examination of the patient's old photographs failed to disclose any facial changes. Thyroid function tests pointed out that free triiodothyronine (FT3) and free thyroxine (FT4) were high in repeated examinations. His laboratory findings are presented in Table I. Radioactive iodine uptake was $25 \%$ and $38 \%$ at 4 th and 24 th hours respectively.

Thyroid ultrasonography showed multiple nodules at the right and left lobe and the parenchyma was homogenous. Thyroid fine needle aspirations from the nodules were benign. The alpha subunit to TSH molar ratio were high. Thyrotropin- releasing hormone injection failed to increase TSH and triiodothyronine suppression test failed to suppress TSH (Figure 1A, B). Octreotide (OCT) test suppressed TSH levels.

Growth hormone levels were not suppressed during the glucose-GH suppression test. Dexamethasone suppression test $(2 \mathrm{mg})$ showed a suppressed cortisol level $(0.38 \mu \mathrm{g} / \mathrm{dL})$.

Pituitary magnetic resonance imaging revealed a $23 \times 22 \times 20$ $\mathrm{mm}$ macroadenoma. The infundibulum was deviated to left and optic chiasm was intact. The patient was given OCT acetate $100 \mathrm{mcg}$ four times daily s.c. for five days for

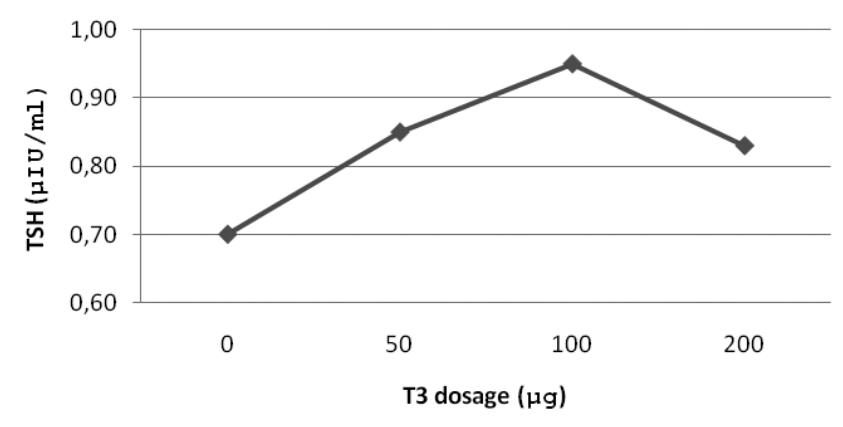

A

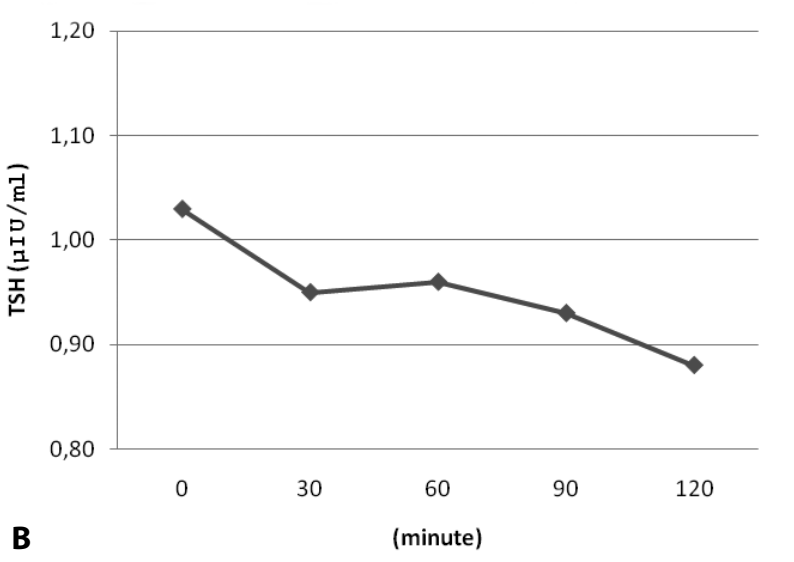

Figure 1: A) T3 suppression test, B) TRH stimulation test.

Table I: Results of the Baseline Endocrine Tests

\begin{tabular}{|c|c|c|}
\hline & Normal Range & Patient's Results \\
\hline Cortisol ( $\mu \mathrm{g} / \mathrm{dl})$ & $8.7-22$ & 18.9 \\
\hline ACTH (pg/dl) & $10-90$ & 31 \\
\hline $\mathrm{FSH}(\mathrm{mlU} / \mathrm{mL})$ & $1.3-13.6$ & 8.62 \\
\hline LH (mIU/mL) & $1.2-10$ & 6.6 \\
\hline Total testosterone $(\mathrm{ng} / \mathrm{mL}$ ) & $2.4-9.5$ & 3.27 \\
\hline Prolactin (ng/mL) & $2.5-18$ & 4.85 \\
\hline $\mathrm{GH}(\mathrm{ng} / \mathrm{mL})$ & $0-10$ & 29.6 \\
\hline IGF-I (ng/ml) & $119-494$ & 927 \\
\hline $\mathrm{TSH}(\mu \mathrm{IU} / \mathrm{ml})$ & $0.35-4.94$ & 1.34 \\
\hline FT3 (pg/ml) & $1.7-3.7$ & 6.68 \\
\hline FT4 ( ng/dl) & $0.7-1.48$ & 2.48 \\
\hline Alpha subunit ( $\mu \mathrm{IU} / \mathrm{ml})$ & $0-0.8$ & 1.3 \\
\hline Anti-T3 antibodies & $<10$ & $<1$ \\
\hline Anti-T4 antibodies & $<15$ & $<1$ \\
\hline SHBG (nmol/l) & $10-80$ & 76 \\
\hline Ferritin (ng/mL) & $28-265$ & 54 \\
\hline CPK (U/L) & $25-200$ & 63 \\
\hline
\end{tabular}

ACTH: corticotropin; CPK: creatinine phosphokinase; FSH: follicle stimulating hormone; FT3: free triiodothyronine; FT4: free thyroxine; GH: growth hormone; IGF-I: insulin-like growth factor 1; LH: luteinizing hormone; SHBG: sex hormone binding globulin. 
controlling hyperthyroidism preoperatively. Transsphenoidal surgery was then performed. The immunohistochemical staining showed that the tumor cells were strongly reactive to $\mathrm{GH}$ and relatively mildly reactive to TSH (Figure 2).

Three months after the operation, the FT3, FT4, GH, IGF-I levels were still high and $\mathrm{GH}$ levels were not suppressed in the glucose-GH suppression test (Figure 3A, B). Pituitary magnetic resonance imaging revealed a $16 \times 18 \times 20 \mathrm{~mm}$ residual macroadenoma. Although the shoe size of the patient did not change during this period of time, mild blunting of the hands was observed. Then second operation was performed transsphenoidally. Three months after operation, IGF-I and FT4 levels were still high (Figure 3A, B). Control pituitary imaging revealed a $14 \times 12 \times 16 \mathrm{~mm}$ residual macroadenoma, so long acting OCT treatment (OCT LAR) of $20 \mathrm{mg}$ a month was administered. However, the patient stopped taking medication without consulting his physician due to financial reasons and did not use medication for 1.5 - 2 years, and did not even come to follow-up visits. The patient was still diagnosed as hyperthyroid as a result of examinations performed at the end of the 2 nd year. Physical examination of the patient revealed blunting of hands, swelling of nose and mild spacing in teeth, and OCT treatment was started again for the patient who had active acromegaly. After two years of treatment, thyroid function tests and IGF-I values were within normal ranges (Figure $3 \mathrm{~A}, \mathrm{~B}$ ). Although there was no significant shrinkage in tumor size as a result of two-year OCT LAR treatment, GH levels were suppressed less than $1 \mathrm{ng} / \mathrm{ml}$ on the glucose-GH suppression test.

\section{DISCUSSION}

Thyrotropin-secreting pituitary adenomas are uncommon neoplasms, accounting for approximately $1 \%$ of all pituitary adenomas and usually appear as macroadenomas (11). The first patient with hyperthyroidism secondary to a TSH-oma was diagnosed by measuring serum TSH levels with bioassay in 1960 (8). Recent years, reported TSH-oma cases were increased due to TSH measurement by means of ultrasensitive immunometric methods (2).

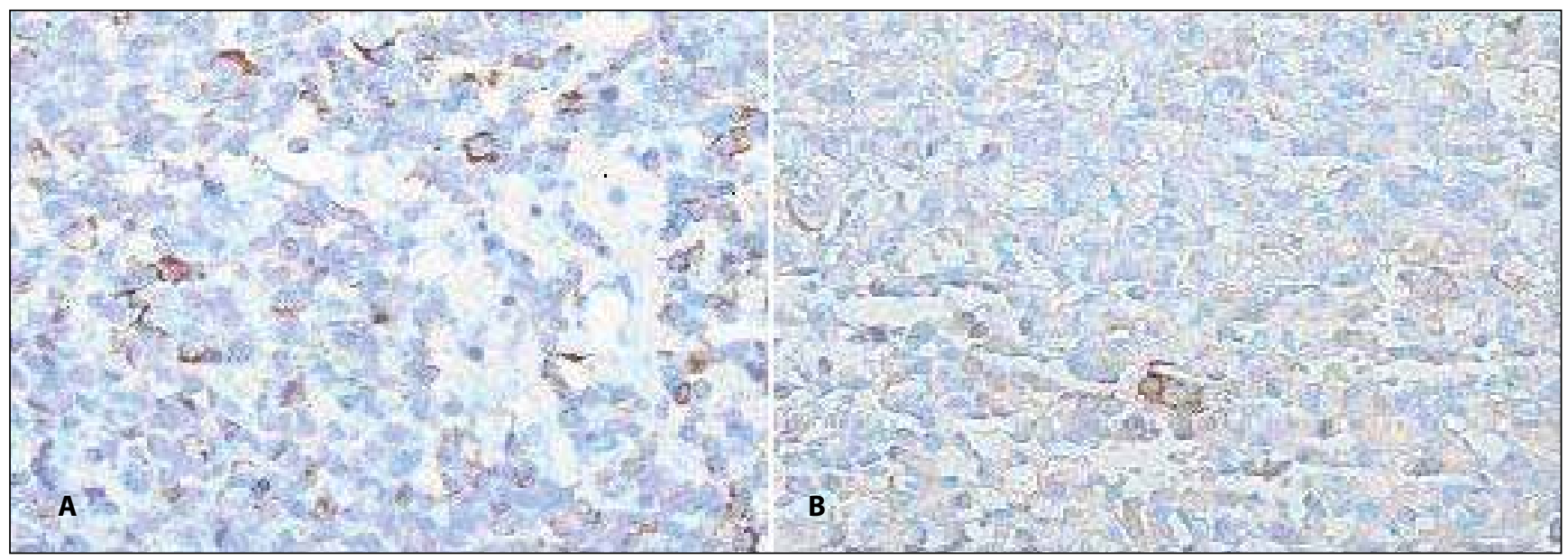

Figure 2: The cells in the surgical specimen showed expression of GH (right) and TSH (left) (x200).

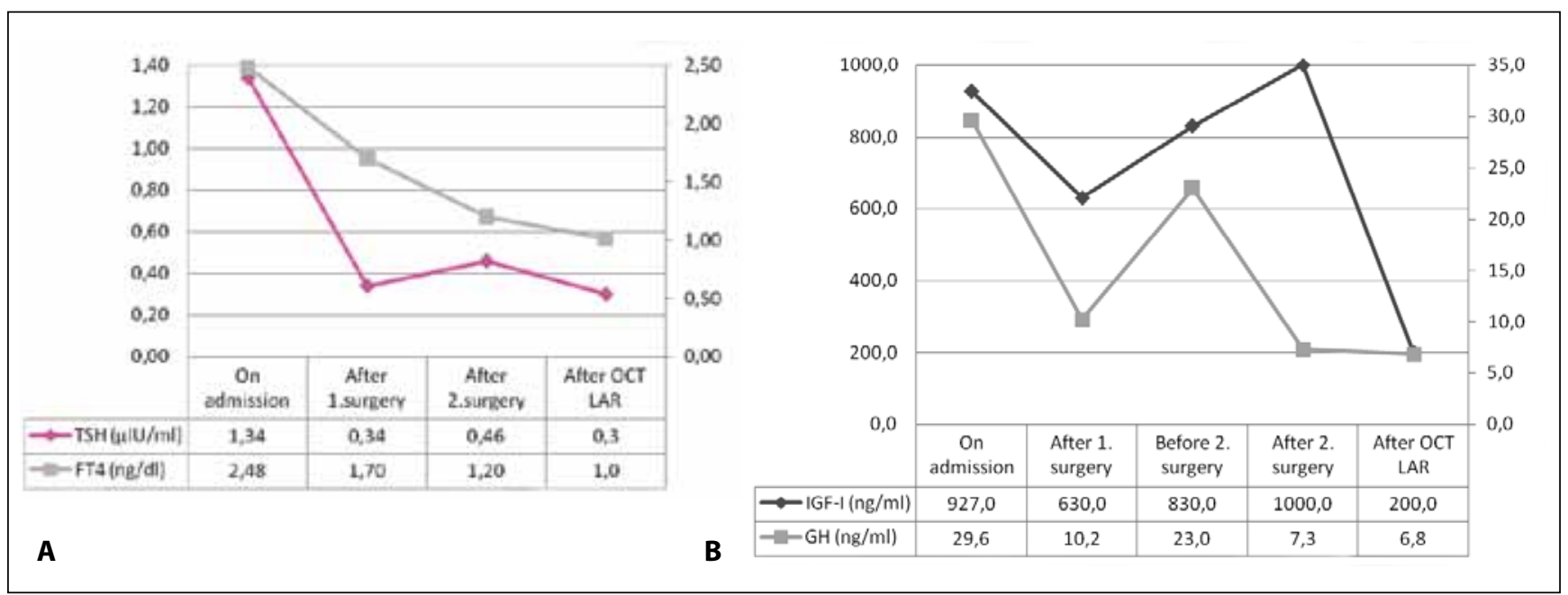

Figure 3: A) Follow-up of thyroid function tests of the patient, B) Follow-up of IGF-I levels of the patient 
Among TSH-oma patients, 71\% show only TSH hypersecretion, and $29 \%$ hypersecretion with other pituitary hormones. The most common co-secreted hormone is the $\mathrm{GH}$. The frequency for growth hormone is $16 \%$, prolactin $11 \%$, FSH and LH $1.4 \%$ (6). Plurihormonal hypophyseal adenomas that secrete TSH and $\mathrm{GH}$ causing hyperthyroidism as in our case were rarely reported in previous years $(4,15)$.

Measurements of several parameters of peripheral thyroid hormone action have been proposed to quantify the degree of tissue hyperthyroidism. In our case, the bone parameters osteocalcin and deoxypyridinoline were high. The reason sex hormone binding globulin (SHBG) level is not high may be SHBG inhibition by $\mathrm{GH}$ that was pointed out previously in $\mathrm{GH}$ and $\mathrm{TSH}$-secreting adenomas (2).

In some cases, especially with $\mathrm{GH}$-secreting adenomas, hyperthyroidism can be masked $(4,12)$. In our case, the clinical signs of thyrotoxicosis were prominent, but the clinical signs of acromegaly were not distinct. Only the patient's nose was slightly enlarged. The admitting complaints "sweating and palpitations" were a result of thyrotoxicosis. Despite high $\mathrm{GH}$ and IGF-I levels, there was no clinical picture of acromegaly. Thus, this clinical picture may be due to low GH biological activity as previously reported with silent somatotropinomas (17). However, this theory was disproved by the elevation of serum IGF-I level. The lack of clinical signs then may be related to short duration of $\mathrm{GH}$ hypersecretion (9). However our patient had macroadenoma indicating that illness onset was not new and it could not be the reason for the mild clinical picture. However, excessive secretion of GH accompanying TSH-oma may have newly started and clinical findings could not appear yet as development of acromegaly may take a few years. Emergence of clinical findings of acromegaly at followup four years after diagnosis supports this theory.

In a study the time of onset of first symptoms and the duration from first symptoms to diagnosis (anamnestic time) were determined retrospectively from clinical, endocrinological, ophthalmological and localizing data in patients with pituitary adenoma (16). It is shown that the median anamnestic time is 5.0 years in women and 5.5 years in men for $\mathrm{GH}$ secreting adenoma. In an epidemiological study analyzing major acromegaly series published between the years 1926 and 1996, the average delay in diagnosis determined from duration of symptoms or changes in photographic appearance was about 8 years (range 6.6-10.2 years) (7).

It has been demonstrated in follow-up of some functional pituitary tumors that they secrete different hormones. A study by Andersen et al. published in 2003 reported acromegaly development in some patients in follow-up of prolactinoma cases and recommended control of IGF-I in annual follow-ups of prolactinoma cases (1). The degree of GH hypersecretion might not have been sufficiently high to cause clinical signs of acromegaly. The answer to this question is still a matter of debate. In 2005 Sen et al. reported high GH and IGF-I levels in a case with silent somatotropinoma as in our patient (14). Otherwise, up to date many studies report slightly high or subnormal growth hormone and IGF-I levels in silent somatotropinomas $(10,13)$.

The first treatment option in TSH-omas and somatotropinomas is surgery, but generally it is not possible to excise these lesions totally as they are usually diagnosed at the macroadenoma stage. These tumors have fibrotic and invasive properties and only $1 / 3$ of patients are surgically cured (12). Pituitary radiotherapy and/or medical treatment with somatostatin analogs are two valid alternatives if surgery is contraindicated or declined, as well as in the case of surgical failure.

Treatment of TSH-omas by somatostatin analogues revealed that $70 \%$ of patients' TSH levels become normal and $38 \%$ of patients' tumor sizes diminish by $20 \%$ (5). In our case, there was still a residual mass after two operations. There was no suppression by dynamic tests and OCT LAR was started. In the second year of OCT LAR, the patient was in remission with normal hormone levels. However, tumor size remained stable and there was no significant shrinkage in tumor size.

In conclusion, the coexistence of TSH-oma and somatropinoma is very rare and contrary to the literature acromegaly signs may be masked despite high $\mathrm{GH}$ and IGF-I levels, thus emphasizing the importance of systematic measurement of GH and IGF-I levels in patients with pituitary adenoma. Somatostatin analogues may be an alternative to surgery with plurihormonal hypophyseal tumors which are not totally excised.

\section{REFERENCES}

1. Andersen M, Hagen C, Frystyk J, Schroeder H, Hagen C: Development of acromegaly in patients with prolactinomas. Eur J Endocrinol 149:17-22, 2003

2. Beck-Peccoz P, Brucker-Davis F, Persani L, Smallridge RC, Weintraub BD: Thyrotropin-secreting pituitary tumors. Endocr Rev 17:610-638, 1996

3. Beck-PeccozP, Persani L: Medical management of thyrotropinsecreting pituitary adenomas. Pituitary 5:83-88, 2002

4. Beck-Peccoz P, Piscitelli G, Amr S, Ballabio M, Bassetti $M$, Giannattasio G, Spada A, Nissim M, Weintraub BD, Faglia G: Endocrine, biochemical, and morphological studies of a pituitary adenoma secreting growth hormone, thyrotropin (TSH), and alpha-subunit: Evidence for secretion of TSH with increased bioactivity. J Clin Endocrinol Metab 62:704-711, 1986

5. Chanson P, Weintraub BD, Harris AG: Octreotide therapy for thyroid-stimulating hormone-secreting pituitary adenomas. A follow-up of 52 patients. Ann Intern Med 119:236-240, 1993

6. Felix I, Asa SL, Kovacs K, Horvath E, Smyth HS: Recurrent plurihormonal bimorphous pituitary adenoma producing growth hormone, thyrotropin, and prolactin. Arch Pathol Lab Med 118:66-70, 1994

7. Holdaway IM, Rajasoorya C: Epidemiology of acromegaly. Pituitary 2:29-41, 1999

8. Jailer Jw, Holub Da: Remission of Graves' disease following radiotherapy of a pituitary neoplasm. Am J Med 28:497-500, 1960 
9. Klibanski A, Zervas NT, Kovacs K, Ridgway EC: Clinically silent hypersecretion of growth hormone in patients with pituitary tumors. J Neurosurg 66:806-811, 1987

10. Kovacs K, Lloyd R, Horvath E, Asa SL, Stefaneanu L, Killinger DW, Smyth HS: Silent somatotroph adenomas of the human pituitary. A morphologic study of three cases including immunocytochemistry, electron microscopy, in vitro examination, and in situ hybridization. Am J Pathol 134: 345-353, 1989

11. Lee EJ, Kim KR, Lee KM, Yoon DH, Kim YS, Kim DI, Jung WH, Chung YS, Lim SK, Lee HC, Huh KB: Thyrotropin-secreting pituitary microadenoma. Yonsei Med J 33:368-373, 1992

12. Losa M, Giovanelli M, Persani L, Mortini P, Faglia G, Beck-Peccoz P: Criteria of cure and follow-up of central hyperthyroidism due to thyrotropin-secreting pituitary adenomas. J Clin Endocrinol Metab 81:3084-3090, 1996

13. Pestell R, Herington A, Best J, Boolell M, McKelvie P, Arnott R, Alford F: Growth hormone excess and galactorrhoea without acromegalic features. Case reports. Br J Obstet Gynaecol 98:92-97, 1991
14. Sen O, Ertorer ME, Aydin MV, Erdogan B, Altinors N, Zorludemir S, Guvener N: Silent pituitary macroadenoma cosecreting growth hormone and thyroid stimulating hormone. J Clin Neurosci 12:318-320, 2005

15. Skorić T, Korsić M, Zarković K, Plavsić V, Besenski N, Breskovac L, Giljević Z, Paladino J: Clinical and morphological features of undifferentiated monomorphous GH/TSH-secreting pituitary adenoma. Eur J Endocrinol 140:528-537, 1999

16. Stoffel-Wagner B, Stöger $P$, Klingmüller D: Initial symptoms and anamnestic time in 517 patients with pituitary adenoma. Dtsch Med Wochenschr 122:213-219, 1997

17. Yamada S, Aiba T, Sano T, Kovacs K, Shishiba Y, Sawano S, Takada K: Growth hormone-producing pituitary adenomas: correlations between clinical characteristics and morphology. Neurosurgery 33:20-27, 1993 